\title{
Disseminated Emergomycosis in a Person with HIV Infection, Uganda
}

\section{Isabelle Rooms, Peter Mugisha, Thilo Gambichler, Eva Hadaschik, Stefan Esser, Peter-Michael Rath, Gerhard Haase, Dunja Wilmes, Ilka McCormick-Smith, Volker Rickerts}

\begin{abstract}
Author affiliations: University Duisburg-Essen, Essen, Germany
(I. Rooms, E. Hadaschik, S. Esser); Mbarara Referral Hospital, Mbarara, Uganda (P. Mugisha); St. Joseph Hospital Bochum, Bochum, Germany (T. Gambichler); University Hospital Essen, Essen (P.-M. Rath); RWTH Aachen University Hospital, Aachen, Germany (G. Haase); Robert Koch Institute, Berlin, Germany (D. Wilmes, I. McCormick-Smith, V. Rickerts)
\end{abstract}

DOI: https://doi.org/10.3201/eid2509.181234

We describe emergomycosis in a patient in Uganda with HIV infection. We tested a formalin-fixed, paraffin-embedded skin biopsy to identify Emergomyces pasteurianus or a closely related pathogen by sequencing broad-range fungal PCR amplicons. Results suggest that emergomycosis is more widespread and genetically diverse than previously documented. PCR on tissue blocks may help clarify emergomycosis epidemiology.

$\mathrm{E}$ mergomycosis is a fungal infection caused by fungi of the newly described genus Emergomyces, of the order Onygenales, which includes obligate fungal pathogens, such as Histoplasma, Blastomyces, and Paracoccidioides (1). Emergomycosis manifests after dissemination to the lungs and skin; it is associated with 50\% mortality. Most cases of emergomycosis have been reported in persons with HIV from South Africa infected with E. africanus, the DNA of which has been amplified from soil there (2). Emergomycosis from E. orientalis or E. canadensis infection has been identified in limited geographic areas.
In contrast, E. pasteurianus infections have been widely documented in Asia, Europe, and South Africa (Appendix Table 2) (2). E. pasteurianus infections were first described in 1998 in a patient in Italy with HIV infection and skin lesions (3). The isolate was initially placed in the genus Emmonsia because of the similarity of the ribosomal large subunit genes. The new genus Emergomyces was suggested by Dukik et al. to distinguish fungi that produce small yeasts in host tissues, comparable to Histoplasma instead of the adiaspores found in Emmonsia (4). We report a case of E. pasteurianus infection in a patient in Uganda with HIV infection.

A 38-year-old woman from Rwanda sought treatment in Uganda for a 3-month history of disseminated skin lesions, nodules, papules, and ulcers (Figure). A chest radiograph revealed no signs of disease. The woman was living in southwestern Uganda, working as a trader. She reported no travel except for a short visit to Dubai 5 years earlier. She had also been diagnosed with HIV 5 years earlier. She was treated for HIV with zidovudine, lamivudine, and nevirapine. CD4 lymphocyte count was 140 cells/ $\mu \mathrm{L}$. HIV viral load testing was not performed.

A skin biopsy was taken, but fungal isolation was not performed because laboratorians lacked the necessary equipment. As therapy for emergomycosis, experts suggest amphotericin B, which was not available for the patient, followed by oral triazoles (2). The patient was started on fluconazole $(400 \mathrm{mg} 1 \times / \mathrm{d})$ for suspected cutaneous cryptococcosis. Histopathology showed narrow budding yeast cells $(2-4 \mu \mathrm{m})$ (Figure). Because skin lesions increased during 6 weeks of fluconazole and antiretroviral treatments, treatment was changed to itraconazole (400 mg $2 \times / \mathrm{d})$. Lesions decreased markedly within 8 weeks, which we considered the key finding suggesting treatment response. No follow-up data are available beyond this point. As reported by Dukik et al., in vitro resistance testing of Emergomyces documents activity of itraconazole, voriconazole, and posaconazole, but not fluconazole (5).

In Germany, DNA was extracted from the formalinfixed, paraffin-embedded (FFPE) skin biopsy as previously described (6). Fungal DNA was amplified by 2 broad-range

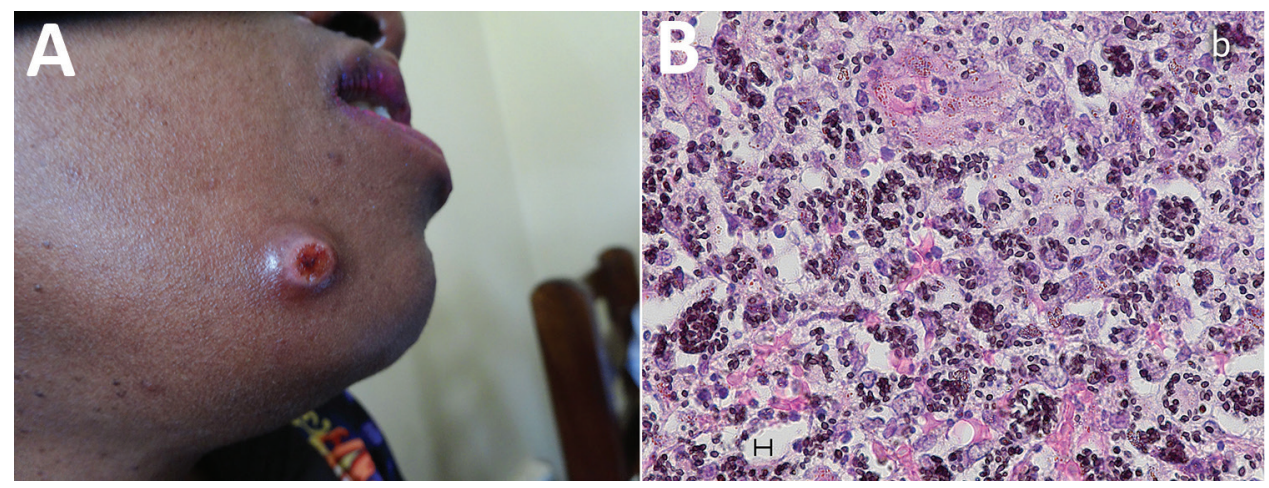

Figure. Imaging from investigation of emergomycosis in a 38-year-old woman from Rwanda with HIV infection living in Uganda. A) Skin lesion on face. B) Histopathology of skin biopsy specimen (Grocott stain) showing multiple budding yeast cells $(2-3 \mu \mathrm{m})$, mostly in clusters. Scale bar indicates $5 \mu \mathrm{m}$. 
PCR assays targeting a region of the $28 \mathrm{~S}$ and the internal transcribed spacer (ITS) 2 regions of the fungal ribosomal RNA genes. Sanger sequencing of the PCR amplicons revealed 365-bp and 273-bp sequences (Appendix, https:// wwwnc.cdc.gov/EID/article/25/9/18-1234-App1.pdf). A BLAST search (https://blast.ncbi.nlm.nih.gov/Blast.cgi) revealed Paracoccidioides lutzii (98.6\% pairwise identity) and E. pasteurianus ( $98.9 \%$ pairwise identity) to be the closest matches for the 28S and ITS2 amplicons. Because no generally accepted pairwise identity break points for fungal species identification are available and sequence data for the region amplified by the $28 \mathrm{~S}$ assay are lacking for many fungi, we sequenced the amplicons of the 2 broad-range PCR assays from fungi of the family Ajellomycetaceae and of the species Coccidioides immitis (Appendix Table 2). Phylogenetic analysis of the concatenated sequences of both broad-range PCR assays suggested that the patient was infected with E. pasteurianus or a closely related species (Appendix Figure).

Identification of fungi from pathology blocks may be used to investigate the etiology of mycosis and define endemic regions of fungal pathogens. However, species identification by histopathology is limited and the optimal molecular identification strategy remains to be defined. Amplification of fungal DNA from FFPE tissue is restricted by amplicon length, PCR inhibition, an excess of host DNA, and contaminating fungal DNA (7). The broad-range assays we used were introduced to amplify fungal DNA from an excess of host DNA. They have been successfully applied on FFPE tissue before $(6,8)$.

The ITS2 assay targets a diverse, noncoding region well represented in public databases. However, variable amplicon length (200-300 bp) suggests that detection limits may vary for different fungi and phylogenetic analysis may be impaired. In contrast, the $28 \mathrm{~S}$ assay amplifies a more conserved coding region (330-350 bp). Whereas identification of a genus may be achieved, species resolution within a genus may not be possible and sequences of this region are underrepresented in public databases $(4,6)$.

Our results suggest that emergomycosis is more widespread and genetically diverse than previously documented. This case suggests that using broad-range fungal PCR assays with specific PCR assays to target prevalent pathogens may be a successful approach for identifying fungal etiology from pathology blocks and defining the epidemiology of emergomycosis and related infections.

\section{About the Author}

Dr. Rooms is a fifth-year resident in dermatology and venereology at the University Hospital of Essen, Germany; she has volunteered as a dermatologist and HIV specialist in Mbarara, Uganda. Her primary interests are tropical dermatological diseases and skin lesions in immunosuppressed patients.

\section{References}

1 Jiang Y, Dukik K, Munoz JF, Sigler L, Schwartz I, Govender N, et al. Phylogeny, ecology and taxonomy of systemic pathogens and their relatives in Ajellomycetaceae (Onygenales): Blastomyces, Emergomyces, Emmonsia, Emmonsiellopsis. Fungal Divers. 2018;90:245-91. https://doi.org/10.1007/s13225-018-0403-y

2. Schwartz IS, Maphanga TG, Govender NP. Emergomyces: a new genus of dimorphic fungal pathogens causing disseminated disease among immunocompromised persons globally. Curr Fungal Infect Rep. 2018;12:44-50. https://doi.org/10.1007/s12281-018-0308-y

3. Gori S, Drouhet E, Gueho E, Huerre M, Lofaro A, Parenti M, et al. Cutaneous disseminated mycosis in a petient with AIDS due to a new dimorphic fungus. J Mycol Med. 1998;8:57-63.

4. Dukik K, Muñoz JF, Jiang Y, Feng P, Sigler L, Stielow JB, et al. Novel taxa of thermally dimorphic systemic pathogens in the Ajellomycetaceae (Onygenales). Mycoses. 2017;60:296-309. https://doi.org/10.1111/myc.12601

5. Dukik K, Al-Hatmi AMS, Curfs-Breuker I, Faro D, de Hoog S, Meis JF. Antifungal susceptibility of emerging dimorphic pathogens in the family Ajellomycetaceae. Antimicrob Agents Chemother. 2017;62:e01886-17. https://doi.org/10.1128/AAC.01886-17

6. Rickerts V, Khot PD, Myerson D, Ko DL, Lambrecht E, Fredricks DN. Comparison of quantitative real time PCR with sequencing and ribosomal RNA-FISH for the identification of fungi in formalin fixed, paraffin-embedded tissue specimens. BMC Infect Dis. 2011;11:202. https://doi.org/10.1186/1471-2334-11-202

7. Rickerts V. Identification of fungal pathogens in formalinfixed, paraffin-embedded tissue samples by molecular methods. Fungal Biol. 2016;120:279-87. https://doi.org/10.1016/ j.funbio.2015.07.002

8. Springer J, McCormick Smith I, Hartmann S, Winkelmann R, Wilmes D, Cornely O, et al. Identification of Aspergillus and Mucorales in formalin-fixed, paraffin-embedded tissue samples: comparison of specific and broad-range fungal qPCR assays. Med Mycol. 2019;57:308-13. https://doi.org/10.1093/mmy/myy041

Address for correspondence: Volker Rickerts, Robert Koch Institute, Seestrasse 10, Berlin 13353, Germany; email: RickertsV@RKI.de 